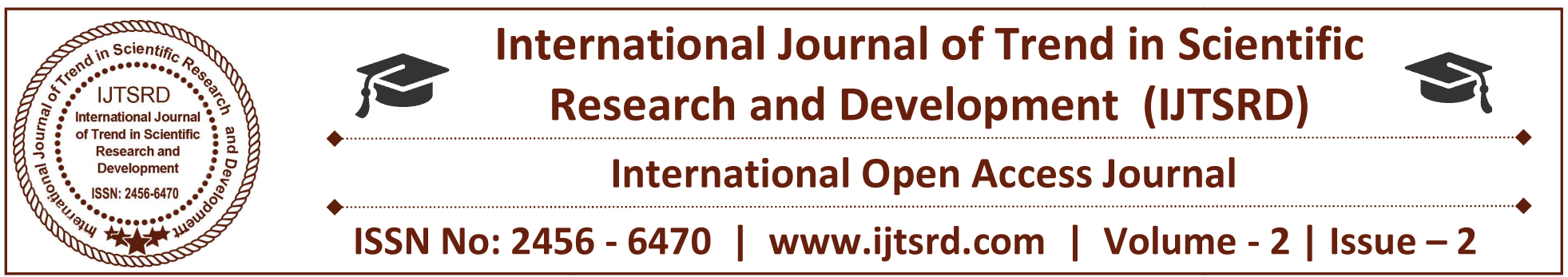

\title{
Factors Influencing Consumer's Thoughts on Green Marketing Practices
}

\author{
Ashok M. V \\ Research Scholar, PP MAN 0590, Rayalaseema \\ University, Kurnool, Andhra Pradesh, India
}

\author{
Dr. Richa Bhalla \\ Associate Professor, Department of MBA, \\ JyotiNivas College, Bangalore, Karnataka, India
}

\section{ABSTRACT}

The developing interest among the customers all over the world concerning safety of surroundings, Worldwide evidence indicates people are concerned about the environment and are changing their behavior. As a result of this, green marketing has emerged which speaks for growing market for sustainable and socially responsible products and services. The main objective is to find the factors influencing consumer's thoughts on green marketing practices. Factors identified may be inter-related but not independent. Hence, the objective is also to group these factors based on the commonalities and name it accordingly. Survey was conducted and consumers have been asked to give their opinion about the factors influencing their thoughts on green marketing practices. The opinion is obtained for twenty-three statements which are related to the factors influencing the consumer's thoughts on green marketing practices by adopting scaling technique, namely, Likert Five Point Scale. A multi-variant statistical technique called factor analysis is applied. In this Principle factor method with orthogonal varimax rotation is used to group the related factors and also other relevant statistical methods are used for data analysis. From the results it is observed that Green Consumer, Environmental Protection, Recycling of Waste, Green Buying Behavior and Preference of Green Products are the identified dimensions (factors), which influence the thoughts of consumers towards green marketing practices.
Keywords: Green marketing, sustainability, Green buying behavior

\section{INTRODUCTION}

Environmentalism has rapidly emerged as a global phenomenon. Advertising and marketing organizations too have risen to the occasion and have commenced responding to environmental challenges through practicing green marketing strategies. green marketing includes the idea of planning, development and promoting of surroundings - pleasant products or services to fulfil the wishes of ultimate clients for fine, quantity, highest quality price and carrier, while not having a negative effect at the usage or its customers. it is a truth that each marketers and clients are increasingly becoming aware about the need to replace over green products and services. The flow from the present advertising strategies to green advertising can also appear to be high priced in the short time period, however it will simply show to be vital and beneficial, and cost effective in the end.

\section{REVIEW OF LITERATURE}

C.L.Hartman ${ }^{1}$ (1997) in his article, "Green alliances: Building New Business with Environmental Groups", enlighten partnerships between businesses and environmental groups, can be effective strategies for integrating corporate environmental responsibilities within market objectives. They are external growth of an emerging philosophy called 'Market-based Environmentalism' which advocates to businesses via 
market incentives. It describes the conceptual underpinnings of the marketplace-primarily based perspective and illustrates how green alliances particularly, are supporting businesses to broaden ecologically protecting programmes that may decrease charges and gives unique advantages to the business.

Jari Karna et al. ${ }^{2}$ (2001) in this study entitled "Social responsibility in environmental marketing planning", the purpose of the empirical study is to measure, describe, and compare how social responsibility is emphasized in the values of members of the forestry wood value chain in four European countries. Social responsibility values of respondents were examined using statements covering economic, ecological, and social aspects of business management.

Oyewole, P. ${ }^{3}$ (2001) in his article, "Social Costs of Environmental Justice Associated with the Practice of Green Marketing”, presents a conceptual link among green marketing, environmental ethics, and industrial ecology. It argues for greater awareness of environmental ethics in the green marketing practices. Again it is suggested to determine consumers' awareness of environmental ethics, and their willingness to pay the costs associated with it.

J.Thorpe and K.Prakash-Mani ${ }^{4}$ (2003) in their work," Developing Value: The Business Case for Sustainability in Emerging Market", explains that how corporate action on sustainability can improve financial performance, the focus of date has been on companies in developed markets. Based on an analysis of more than 240 case studies from over 60 countries, this study focuses on addressing the gap. It analyses the "business case" for sustainability in emerging markets, identifying opportunities for businesses to cut shot the costs, increase the sales, minimize the risks, develop manpower capital, build reputation, and enhance access to capital from better corporate governance, improved environmental practices, and investments in social and economic development.

Sheenu Jain" (2007) in their article, "Green Marketing: An Illusion or Reality" highlights the need to address sustainability is a serious issue, however there have also been moments of farce, in particular in terms of some of the early green marketing claims. furthermore, there has been an ironic detail to lots of the dialogue approximately the inexperienced advertising and marketing up to now due to the fact, from a theoretical point of view, green advertising has been seriously restrained by its emphasis on the buying aspect of the intake technique. Environmental amelioration has been largely portrayed as a query of clients expressing their worries by means of shopping new greener products.

H.Ramakrishna ${ }^{6}(2012)$ in his article on "Green Marketing in India: Some Eco- Issues", deals with environmental marketing satisfies human needs with minimal detrimental impact on the natural environment. At the same time it should be noted that in the era of green marketing, each and every stakeholder should take part in this access a social responsibility. The terms like "green marketing", "Ecological advertising and marketing" and "Environmental marketing" are becoming famous in modern days. To analyze the legal environment of green marketing across the globe, with special reference to the Indian researcher also intended to draw the attention of traditional customers towards green marketing. Now - a- days, the consumers are getting quite aware about the importance of the protection of the earth. Protecting the ozone layer, pollution of air, water and environment from print and non-print media. Therefore, in order to survive in the present era of cut-throat competition, firms need to go greener than their competitors.

R. Shrikanth and D.Surya Narayana Raju ${ }^{7}$ ( 2012) in their study," Contemporary green marketing - Brief reference to Indian scenario", analysed that green marketing have to now not be considered as simply one greater approach to marketing, as a substitute must be pursued with greater vigor as it has societal and environmental dimensions. marketers moreover have the duty to make the stakeholders aware about the want and the blessings of inexperienced products.

Susmitha Mohan and Dr.Philo Francis ${ }^{8}$ (2014) in their article, "Green Marketing: An initiative for Green growth" entitled companies have developed and adopted GM strategies as a part of their corporate social responsibility (CSR) strategies in order to meet the economic development. At the same time, they also consider environmental protection. Thus there is an inter connection between CSR, sustainable development and GM activities and this will lead to green growth and will develop a green economy.

P.Purushotham and B. SaarangaPaani ${ }^{9}(2014)$ in their article, "Green energy technologies: Key to india's 
energy independence" highlights the national energy policy, agriculture policy, transport policy and fiscal policies should go hand in hand such that they mutually aid and reinforce the objective of achieving sustainable development. Green technologies offer vast scope for decentralizing power generation by which the renewable energy technology boom could do to power industry what the internet did to the depth, range, speed and cost of media.

\section{OBJECTIVES OF STUDY}

1. To find the factors influencing consumer's thoughts on green marketing practices.

2. To group these factors based on the commonalities and name it accordingly.

\section{RESEARCH \\ METHODOLOGY}

DESIGN

The study is descriptive based on both the primary and secondary data. The research problem, the hypotheses have been formulated and framed accordingly. The suggestions of the study emerge from the inferences drawn from the sample survey of consumers, retailers and manufacturers in Tumkurdistrict.

The secondary data were collected from standard text books related to topic, leading journals, published reports and booklets, documents and records of the Government departments and the internet.

The present study is an empirical one based on survey method. First hand data were collected from the field through interview schedule. In this study, the researcher prepared three interview schedules, one for consumers, one for retailers and the other one for manufacturers.

Data relating to the green marketing practices of consumers, retailers and manufacturers are collected through the separate interview schedules. A number of discussions were held with knowledgeable persons such as academicians, government officials and NGOs for designing the interview schedule.

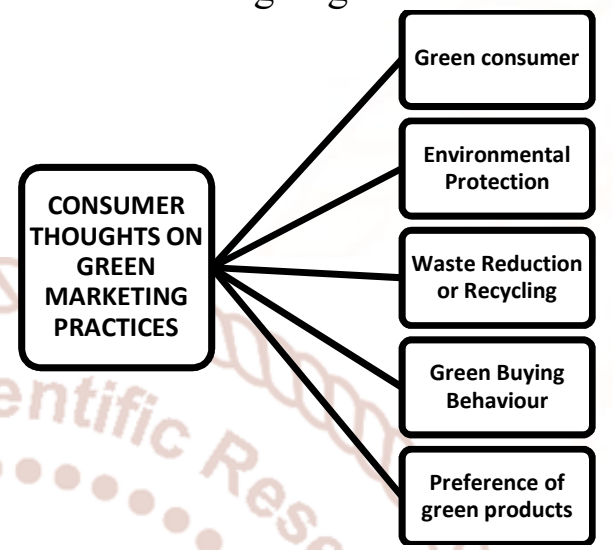

Fig 1: Factors Influencing Consumer's Thoughts On Green Marketing Practices

\section{ANALYSIS}

During the survey, the consumers are asked to give their opinion about the factors influencing their thoughts on green marketing practices. The opinion is obtained for twenty three statements which are related to the factors influencing the consumer's thoughts on green marketing practices by adopting scaling technique, namely, Likert Five Point Scale. Table1 shows the details of about consumer's thoughts on green marketing practices.

TABLE 1: Consumer Thoughts on Green Marketing Practices

\begin{tabular}{|c|c|c|c|c|c|c|c|}
\hline SI. & Particulars & V.S.A. & S.A. & A. & D.A. & S.D.A. & Total \\
\hline No. & & -5 & $-4>-5$ & -3 & -2 & -1 & Score \\
\hline \multirow[t]{2}{*}{1} & I know Green Products & 139 & 150 & 85 & 8 & 2 & 384 \\
\hline & & $36.20 \%$ & $39.06 \%$ & $22.14 \%$ & $2.08 \%$ & $0.52 \%$ & $100 \%$ \\
\hline \multirow[t]{2}{*}{2} & $\begin{array}{l}\text { I am always using organic } \\
\text { products }\end{array}$ & 63 & 149 & 141 & 30 & 1 & 384 \\
\hline & & $16.41 \%$ & $38.80 \%$ & $36.72 \%$ & $7.80 \%$ & $0.27 \%$ & $100 \%$ \\
\hline \multirow[t]{2}{*}{3} & $\begin{array}{l}\text { I buy environmentally friendly } \\
\text { products with my friends }\end{array}$ & 69 & 139 & 133 & 38 & 5 & 384 \\
\hline & & $17.97 \%$ & $36.20 \%$ & $34.64 \%$ & $9.89 \%$ & $1.30 \%$ & $100 \%$ \\
\hline \multirow[t]{2}{*}{4} & $\begin{array}{lll}\text { I always } & \text { share } & \text { information } \\
\text { regarding } & & \text { eco-friendly } \\
\text { products } & \text { with } & \text { my family } \\
\text { members } & & \end{array}$ & 72 & 138 & 135 & 35 & 4 & 384 \\
\hline & & $18.75 \%$ & $35.95 \%$ & $35.16 \%$ & $9.11 \%$ & $1.04 \%$ & $100 \%$ \\
\hline
\end{tabular}


Similarly factors like ; I buy green products even if they are more expensive than the non-green ones; I often urge my friends to use products that advertised as being green ;I would be willing to stop buying products from companies guilty of harming the environment even though it might be inconvenient; I refuse to buy companies accused of being pollution;I buy products in refillable containers ; I read labels to see if contents are environmentally safe; I avoid to buy the products in aerosol containers; I believe recycling will reduce pollution Recycling is important to save ; Recycling is important to save natural resources ;I am always maintaining biodegradable wastes from non-degradable; I don't throw non biodegradable waste in the open areas surroundings; I would like to watch green advertisements more; I know the most of the green companies ; I am a dark green buying green products or using Green Services); I bring my own shopping bags instead of using plastic bags or paper sacks offered by seller.

Table 1 discloses that majority of the consumers agree with all the factors in connection with their thoughts about green marketing practices, the percentage is high for 'Agree', and 'Strongly Agree' scales.

\subsection{FACTOR ANALYSIS}

There are about 17 factors identified by the researcher. These factors are inter-related but not independent. Hence, in order to group the related variables the factor analysis has been applied. Factor analysis is a multi-variant statistical technique that explains the inter-relationship among the total set of observed variables. Factor analysis is a way of grouping of variables based on the criterion of common characteristics which would serve as a common denominator for such a classification. It is an analytical tool which can aid preliminary investigations and in the interpretation of the relationship among a large number of inter-related and inter-dependent variables.

But the principle factor method with orthogonal varimax rotation is mostly used and widely available in the factor analytic computer programme. One of the final outcomes of a factor analysis is called rotated factor matrix, a Table of coefficients that expresses the relation between the variables and the factors that have been prepared. The sum of squares of the factor loading of a variable is called communalities $\left(\mathrm{h}^{2}\right)$.

The communalities of a factor is its common factor variance. The factors where factor loading is 0.50 or greater are considered significant factors. In the present study the principal factor analysis method with orthogonal varimax rotation is used to identify the significance of different variable of consumer's thoughts on green marketing practices. The estimated results are given in Table.

The rotated factor loading received by factors $\mathrm{F}_{1}, \mathrm{~F}_{2}$, $\mathrm{F}_{3}, \mathrm{~F}_{4}$, and $\mathrm{F}_{5}$ are presented in Table 2

Table 2 ROTATED FACTOR MATRIX WTH COMMUNALITIES (Consumers' Overall Thoughts on Green Marketing Practices in TumkurDistrict)

\begin{tabular}{|c|c|c|c|c|c|c|}
\hline \multirow[t]{2}{*}{ Statement } & \multicolumn{5}{|c|}{ NUMBBER OF FACTORS } & \multirow[b]{2}{*}{ Communality } \\
\hline & F1 & F2 & F3 & F4 & F5 & \\
\hline $\begin{array}{l}\text { I would like to watch green } \\
\text { advertisements more }\end{array}$ & 0.745 & 0.128 & 0.13 & 0.041 & 0.086 & 0.598 \\
\hline $\begin{array}{l}\text { I know the most of the } \\
\text { green companies }\end{array}$ & 0.719 & 0.222 & -0.079 & 0.112 & -0.028 & 0.586 \\
\hline $\begin{array}{l}\text { I am a dark green } \\
\text { consumer }\end{array}$ & 0.668 & 0.016 & 0.212 & 0.084 & 0.243 & 0.558 \\
\hline $\begin{array}{l}\text { Supporting environmental } \\
\text { protection makes are more }\end{array}$ & 0.018 & 0.66 & 0.062 & 0.239 & -0.048 & 0.499 \\
\hline $\begin{array}{l}\text { I buy environmentally } \\
\text { friendly products with my } \\
\text { friends }\end{array}$ & 0.254 & 0.612 & 0.014 & 0.013 & 0.072 & 0.445 \\
\hline
\end{tabular}

\section{FACTOR I: GREEN CONSUMER}

Consumes are the real assets of a business organization. Every business depends on its customers. Till a few years ago, consumers worried about the quality, quantity and price of products. But in the present scenario, consumers are also worrying about safeguarding the environment. So consumers 
are important drivers behind the move to save the environment. Such consumers are called green consumers.

Among the variables, I would like to watch green advertisements more (0.745), I know the most of the green companies (0.719) and I am a dark green consumer (0.668) are the items with high loading on Factor 1. The Factor I is characterized as "Green Consumer". The percentage of variance is 11.016. All these variables have a high communality indicating that the variables within Factor 1 have very high association among them.

\section{FACTOR II: ENVIRONMENTAL PROTECTION}

Green marketing is a device for protecting the surroundings for the present and future generations. It has a fantastic effect on environmental protection. because of the developing challenge of environmental protection, there may be an emergence of a brand new marketplace that's the green market.

In the second factor, supporting environmental protection makes a more (0.660), I buy environmentally friendly products with my friends (0.612), when I want to buy a product, I look at the ingredients label to see if it contains that one environmentally damaging (0.609) and I know green products $(0.585)$ have the highest significant positive loadings. Asthe above items relate to environmental protection, factor II is termed as 'Environmental Protection'. The percentage of variance is 10.054 . The higher factor loading on its variableshelps in identifying the variables associated with Factor II. All the variables have high communality indicating that the variables within Factor II have very high association.

\section{FACTOR III: RECYCLING OF WASTE}

Recycling is the procedure of collecting and processing materials that could otherwise be thrown away as trash and turning them into new merchandise. it is able to advantage our community and the environment. It reduces the quantity of waste ship to landfills and incinerators and it also conserves natural resources.

It is observed from this Table that the statements like I believe recycling will reduce pollution (0.695), I am always separating and maintaining bio-degradable wastes from non-biodegradable (0.542), and I bring my own shopping offered by sellers (0.504) and the items with high loadings on factor III. All the variables on the above are related to recycling, factor III is characterized as 'recycling'. The percentage of variance is 9.001. The higher factor loading on the statements indicate that Factor III underlies these variables. The higher value of communality for the above statements indicates that a higher amount of variance is explained by the extracted factors.

\section{FACTOR IV: GREEN BUYING BEHAVIOUR}

Green Consumerism must be encouraged by educating or creating awareness about eco-friendly buying behavior. Final consumers also have the ability to pressure organizations to integrate the environment into their corporate culture and thus ensure all organizations minimize the detrimental impact of their activities. It is possible when using green buying behavior.

In the fourth factor, I buy products in reliable containers (0.727), I avoid to buy the products in aerosol containers (0.646) and I would be willing to stop buying from companies guilty to harming the environment even though it might be $(0.514)$ have the highest factor loadings. As the above variables are relate to the attitude of buying behaviour of customers. It is termed as 'Green Buying Behaviour'. The percentage of variance is 7.24. The highest values of communality of these variables indicate that a higher amount of variance is explained among the variables.

\section{FACTOR V: PREFERENCE OF GREEN PRODUCTS}

Green Product means a product made from any ecofriendly raw material and it do not give any negative impact on the environment. Consumers prefer a product when its environmental benefits are tangible and can be clearly and simply communicated.

In the fifth factor, I often urge my friends to use products that advertised as being green (0.601), I prefer green products over non-green products where their product qualities as similar (0.555), and I am interested to switch over to other brand for ecologist reasons (0.508), have the highest significant positive loadings. As the above variables are related to preference for buying green product. Factor $\mathrm{V}$ is characterized as 'Preference of green product'. The percentage of variance is 7.698. The higher factor 
loadings indicate that Factor $\mathrm{V}$ underlies the above two variables. The high communality value indicates that the variables within Factor $\mathrm{V}$ have a very high association among them.

\section{FINDINGS AND SUGGESTIONS}

The attitude of manufacturers has been measured by adopting Likert's ScalingTechnique. The attitude has been categorized in to three levels namely high, medium andlow.Out of 168 sample manufacturers, 18.45 per cent, 61.31 per cent and 20.42 per cent of them come under the category of high, medium and low level attitude, respectively.

In order to examine the relationship between the business profile factors and level of attitude of the manufacturers towards green marketing practices, two way ANOVA and Chi-square Test is applied. The results reveal the fact that the factors like types of business, type of ownership, age of the business and net worth of the business have not influenced the level of attitude of the manufacturers regarding the green marketing practices.

Regarding the factor analysis, the following factors are extracted that influence the attitude of manufacturers towards the green marketing practices:

1. Effort Taken for Making Green Environment

2. Waste Maintenance

3. Inducement for Stabilizing Green practices

4. *Pollution Control

5. Proper Maintenance and Usage

6. Monetary Aid for Protecting Nature

7. Development of Green Region

8. Keeping fit of Green Production Methods

9. Recycling of Waste

\section{CONCLUSION}

The main objective was to find the factors influencing consumer's thoughts on green marketing practices. The objective was also to group these factors based on the commonalities and name it accordingly. Opinion regarding objectives were collected from consumers using survey by adopting scaling technique, namely, Likert Five Point Scale. Factor analysis, multi-variant statistical tool is used for data analysis. In this Principle factor method with orthogonal varimax rotation was used particularly to group the related factors. Green Consumer, Environmental Protection, Recycling of Waste, Green Buying Behavior and Preference of Green Products were the dimensions (factors)which are obtained as result, that influence the thoughts of consumers towards green marketing practices.

\section{REFERENCES}

1. C.L.Hartman, "Green alliances: Building New Business with Environmental Groups", The Journal of Long Range Planning, Vol. No. 30 No.2, April 1997,pp. 184 - 190.

2. JariKärna, Eric Hansen, HeikkiJuslin and Helsinki, "Social responsibility in environmental marketing planning'European Journal of Marketing Vol. 37 No. 5/6, 2003 pp. 848-87.

3. P.Oyewole, "Social Costs of Environmental Justice Associated with the Practice of Green Marketing", Journal of Business Ethics, Vol. No.29 No.3, February2001, pp. 239 - 252.

4. J.Thorpe and K.Prakash-Mani," Developing Value: The Business Case forSustainability in Emerging Market", Greener Management International, Vol.No.44, January 2003, pp. 1733.

5. Sheenu Jain, "Green Marketing: An Illusion or Reality", Indian Journal ofMarketing (IJM), Vol.30, Issue No.5, May 2007, pp. 17-24

6. H. Ramakrishna., "Green Marketing in India: Some Eco-Issues", Indian Journalof Marketing (IJM), Vol.5, Issue No.11, November 2012, pp.715.

7. R. Shrikanthand D.Surya Narayana Raju, "Contemporary green marketing -Brief reference to Indian scenario", International Journal of Social Sciences \&Interdisciplinary Research, India, Vol.1 No. 1, January 2012, pp.28-39.

8. Susmitha Mohan and Philo Francis, "Green Marketing: An initiative for Green growth", Business and EconomicFacts for You, Vol 34, May 2014, p-28.

9. P.Purushotham and B. SaarangaPaani, "Green energy technologies: Key to india's energy independence", Facts for You, Vol 32, April 2014, p -39. 